\title{
PERLINDUNGAN HUKUM BAGI PEKERJA TOKO MODERN YANG TERKENA PEMUTUSAN HUBUNGAN KERJA (PHK) SECARA SEPIHAK AKIBAT DAMPAK PANDEMI COVID-19 DI KOTA DENPASAR
}

\author{
G. A. A. Anindyanari Auliani Dewi, I N. Putu Budiartha, Ni M. Puspasutari Ujianti \\ Fakultas Ilmu Hukum Universitas Warmadewa, Denpasar - Bali, Indonesia \\ anindyanariad97@gmail.com, budiarthaputu59@gmail.com,puspasutariujianti@gmail.com
}

\begin{abstract}
Abstrak
Pengakhiran ikatan kerja masih sering dilaksanakan pemilik usaha kepada para pekerjanya. Salah satunya yaitu yang dilakukan para pemilik usaha Toko Modern yang ada di Denpasar akibat dari dampak Covid-19 yang terjadi di Indonesia. Mereka melakukan pemberhentian pada para buruh Toko Modern tanpa perundingan sebelumnya. Penelitian ini bertujuan untuk menggambarkan bagaimana pengaturan hak-hak dan perlindungan hukum bagi pekerja jika mengalami PHK secara sepihak oleh pemilik usaha. Penelitian ini merupakan penelitian hukum empiris. Data diperoleh dari tanya jawab dan riset kepustakaan. Dalam upaya melakukan perlindungan hukum terhadap para pekerja toko modern yang terkena PHK secara sepihak, pemerintah telah mengeluarkan beberapa peraturan terkait permasalahan pengakhiran ikatan kerja yang dilaksanakan pemilik usaha. Selain itu, hak-hak para pekerja yang terkena PHK harus diperhatikan seperti pemberian uang pesangon dan ganti kerugian serta menjamin perlindungan hukumnya dengan memberikan perlindungan hukum secara preventif dan represif agar para pemilik usaha tidak sewenang-wenang melakukan PHK.
\end{abstract}

Kata Kunci: Covid-19, Pekerja, Pemilik Usaha, Perlindungan Hukum, Pemutusan Hubungan Kerja

\begin{abstract}
The termination of the work bond is often carried out by business owners to their workers. One of them is what Modern Store business owners in Denpasar did as a result of the impact of Covid-19 that occurred in Indonesia. They stopped the Modern Shop workers without prior negotiation. This study aims to describe how the rights and legal protection arrangements for workers if they experience unilateral dismissal by the business owner. This research is empirical legal research. Data were obtained from question and answer and library research. In an effort to provide legal protection for modern shop workers who are unilaterally laid off, the government has issued several regulations related to the issue of terminating the work bond carried out by business owners. In addition, the rights of workers affected by layoffs must be considered, such as giving severance pay and compensation and guaranteeing legal protection by providing preventive and repressive legal protection so that business owners do not arbitrarily lay off workers.
\end{abstract}

Keywords: Covid-19, Workers, Business Owners, Legal Protection, Termination of Employment

\section{PENDAHULUAN}

Indonesia merupakan sebuah negara yang di dalamnya terdapat perekonomian yang berkembang sangat pesat bahkan merupakan yang terdepan dari Asia Tenggara di samping negara satunya yaitu China. Dari negara ini dibangun, masyarakat kita sudah paham bahwa mata pencaharian adalah keperluan masyarakat agar mendapatkan penghidupan yang baik dan memadai untuk mereka sendiri.

Perekonomian di Indonesia terus berkembang secara signifikan dan meningkat di setiap tahunnya. Namun, sejak Desember 2019 dunia dikejutkan dengan berita adanya wabah penyakit baru yang menyerang kota Wuhan, China. Wabah ini bernama Coronavirus, dimana wabah ini adalah salah satu wabah yang amat mematikan utamanya menyerang sistem pernapasan pada makhluk hidup khususnya manusia. Akibat penyebarannya yang sangat cepat dari manusia ke manusia lainnya membuat hampir sebagian Negara akhirnya melakukan penutupan di negara mereka untuk menahan perluasan yang semakin meluas dari dalam maupun di luar Negara mereka sendiri. Namun pemberlakuan lockdown di beberapa Negara ini menyebabkan perekonomian dunia menjadi terganggu dan bahkan krisis global mulai terjadi di beberapa Negara tak terkecuali yang saat ini 
sedang melanda negara kita yaitu Negara Indonesia (Muhyiddin, 2020). Menyikapi hal ini akhirnya Pemerintah Indonesia memberlakukan keputusan dengan mengurangi aktifitas masyarakatnya atau PSBB yang diharapkan dapat menahan perluasan wabah tersebut di Indonesia.

Namun, akibat pemberlakukan kebijakan PSBB yang dilakukan oleh Pemerintah, perekonomian di Indonesia mulai mengalami kemerosotan yang sangat tajam. Kemerosotan perekonomian yang terjadi di Indonesia juga disebabkan karena kurangnya daya beli masyarakat sejak wabah Covid-19 menyerang Indonesia. Padahal, masyarakat harus selalu memenuhi kebutuhannya sehari-hari untuk tetap melaksanakan penghidupan mereka seperti biasa. Dari hubungan bantumembantu inilah tercipta suatu hubungan perburuhan atau hubungan kerja antara pemberi kerja (pengusaha/majikan) yang memerlukan bantuan orang lain (tenaga kerja) untuk memudahkan pekerjaannya dengan pihak tenaga kerja yang memerlukan penghasilan untuk memenuhi kebutuhan hidupnya.

Untuk mewujudkan kemajuan dunia usaha, harus terdapat keseimbangan antara pemberi kerja atau pengusaha dengan pekerja/buruh atau tenaga kerja (Hakim \& Ispriyarso, 2016; Sholeh, 2007). Tetapi hal ini biasanya sangat sulit untuk diwujudkan karena pengusaha atau pemberi kerja memiliki kedudukan yang sangat kuat jika dibandingkan dengan pekerja/buruh atau tenaga kerja itu sendiri. Karena hal inilah sering sekali terjadi penyimpangan hak- hak pekerja atau buruh itu sendiri. Hubungan pemilik suatu usaha dengan penerima pekerjaan ini disebut sebagai hubungan kerja. Hubungan kerja ini diwujudkan berdasarkan perjanjian kerja yang mempunyai unsur pekerjaan, upah dan perintah di dalamnya. Jarak waktu sebuah perjanjian kerja dibagi menjadi dua yaitu kesepakatan kerja yang waktunya ditentukan oleh kedua belah pihak dan kesepakatan kerja yang waktunya tidak ditentukan oleh kedua belah pihak (Suratman, 2019).

Tetapi seringkali pekerja/buruh kurang memahami hak-hak yang perlu mereka dapatkan selama mereka mengikatkan diri di dalam perjanjian kerja tersebut. Setiap perilaku menurut hukum adalah kemauan para pihak itu sendiri secara berdaulat dan bukan akibat dari kewajiban atau dapat ijin menurut sebuah aturan undang-undang (W, Sulastri, \& R, 2018). Sehingga akibat kurangnya pemahaman tentang hal ini, PHK secara satu sisi yang diperbuat oleh pemilik sebuah usaha kepada penerima pekerjaan sering terjadi. Faktanya bahwa sejak krisis ekonomi yang terjadi di Indonesia akibat dampak pandemi Covid-19, banyak pekerja/buruh yang di PHK secara satu sisi oleh pemilik suatu tempat usaha atau dimana mereka bekerja. Tak terkecuali para pekerja/buruh yang bekerja di Toko Modern ikut menjadi korban PHK secara sepihak yang diperbuat oleh orang yang mempunyai Toko Modern di wilayah Denpasar.

Akibat dari adanya wabah Covid-19 sejak Maret 2020, para pemilik usaha Toko Modern mengakui bahwa terdapat penurunan penjualan yang sangat signifikan setiap harinya karena daya beli masyarakat yang mulai menurun akibat pembatasan ruang gerak dan krisis ekonomi yang terjadi, terlebih di Denpasar masih menerapkan pembatasan jam malam untuk seluruh toko yang ada untuk mengurangi keramaian dan kerumunan yang terjadi di masyarakat. Sejak adanya Pandemi Covid-19 ini dan Pemerintah menghimbau menerapkan PSBB di beberapa wilayah, penjualan di toko kami mengalami penurunan hampir 30\% setiap harinya. Makanya kami juga terpaksa mengurangi jumlah pekerja di toko karena ketidakmampuan kami memberikan gaji (Wawancara dengan Bapak I Nyoman Widnya Pemilik Toko Modern Zenmart di Jalan Sedap Malam No. 12). Pekerja/buruh yang memang sangat kurang pengetahuan akan hak-hak mereka hanya bisa pasrah menerima ketika mereka di-PHK secara sepihak tanpa mencoba mempertahankan hak-hak mereka terlebih dahulu.

Akan lebih baik apabila pembangunan sebuah ketenagakerjaan perlu dikaji ulang sehingga memenuhi hak-hak, selain itu perlindungan dimana mudah dipahami oleh para pekerja dan pada saat yang sama mampu memperoleh keadaan yang baik untuk pembangunan dunia kerja itu sendiri (Wijayanti, 2010). Untuk itulah sangat diperlukan adanya jaminan atas hak-hak buruh/pekerja itu sendiri terlebih pekerja yang bekerja di toko modern dan perlindungan hukum tanpa adanya unsur diskriminasi untuk menjamin adanya kepastikan hukum ketika terjadinya pemutusan hubungan kerja untuk menjamin para pekerja atau buruh dan keluarganya dengan tetap berpedoman dan melihat seberapa baik kemajuan dunia usaha yang ada.

Berdasarkan pemaparan yang telah diuraikan di atas penelitian ini dilakukan dengan tujuan mendeskripsikan pengaturan hak-hak pekerja jika mengalami Pemutusan Hubungan Kerja (PHK) secara sepihak oleh pemilik usaha Toko Modern di Kota Denpasar dan menggambarkan perlindungan 
hukum bagi pekerja toko modern yang terkena Pemutusan Hubungan Kerja (PHK) secara sepihak akibat dampak pandemi Covid-19 di Kota Denpasar.

\section{METODE PENELITIAN}

Penelitian ini didesain dengan tipe penelitian yuridis empiris. Penelitian yuridis empiris merupakan sebuah metode penelitian yang dimana mempergunakan sumber primer sebagai pedomannya dan juga menggunakan atau megacu kepada problematika yang ada di masyarakat. Pendekatan masalah yang dipergunakan adalah pendekatan secara sosiologis hukum. Maksudnya adalah masalah yang muncul itu dikaji berdasarkan sebuah teori yang ada atau ketentuan hukum yang mengaturnya, lalu semua hal itu dikaitkan satu sama lain dengan kenyataan atau kejadian yang benar-benar terjadi di lapangan.

Adapun sumber data yang digunakan dalam penelitian ini diperoleh dari dua sumber yaitu sumber data primer dan sumber data sekunder. Sumber data primer adalah data yang didapat langsung dari masyarakat sebagai sumber pertama dengan melalui penelitian lapangan atau "Field Research", yang dilakukan baik melalui wawancara atau interview. Dalam hal ini pengumpulan data diperoleh melalui hasil observasi serta wawancara secara langsung yang dilakukan kepada pemilik usaha toko modern yang ada di Kota Denpasar dan sumber data sekunder adalah data yang diperoleh dari studi kepustakaan. Untuk lokasi penelitian, beberapa toko modern yang ada di wilayah Kota Denpasar dipilih dengan cara menggunakan teknik pengumpulan data melalui observasi, wawancara dan studi kepustakaan. Data yang sudah terkumpul dianalisis menggunakan metode deskripif dan disajikan secara informal.

\section{HASIL DAN PEMBAHASAN}

\section{Pengaturan Hak-Hak Pekerja jika Mengalami Pemutusan Hubungan Kerja (PHK) Sepihak pada Toko Modern di Kota Denpasar}

Suatu hubungan kerja biasanya merupakan sebuah perjanjian yang mana perjanjian ini sudah disepakati oleh dua orang yang saling membuat janji untuk melakukan sesuatu hal yang telah mereka sepakati (Setiawan, 2018). Salah satu seorang Hakim pernah memberikan pendapatnya mengenai PHK ini. Hakim yang merupakan ahli hukum ini memberikan pendapatnya bahwa PHK adalah pengakhiran suatu hubungan yang dilakukan oleh pemilik tempat usaha atau sebuah perusahaan dengan pegawainya yang bekerja di tempat itu atau yang sering kita sebut sebai pekerja atau buruh.

Jika suatu hubungan atau keterkaitan antara pemilik tempat usaha ini dengan pegawainya berakhir, maka mereka satu sama lain tidak memiliki hak dan kewajiban untuk memenuhi apa yang sudah diperjanjikan sebelumnya seperti misalkan saja sang pemilik tempat usaha tidak berwenang memberikan gaji lagi dan pegawai tersebut juga tidak mempunyai kewajiban untuk melakukan pekerjaan atau perintah yang disuruh oleh pemilik tempat usaha tersebut. Pemutusan hubungan kerja dapat terjadi dengan empat cara, yaitu PHK demi hukum, PHK atas keputusan pengadilan/PPHI, PHK atas kehendak pekerja atau buruh dan PHK atas kehendak pemilik usaha. Dari keempat bagian itu masing- masih memiliki cara pandang dan akibat hukum yang berbeda satu sama lainnya dalam hal memberi sebuah ganti rugi dan pemenuhan hak pekerja yang terkena PHK itu sendiri. Oleh karena adanya pemutusan hubungan kerja tersebut maka tentu saja akan menggangu rantai hak dan kewajiban yang sudah terdapat didalamnya. Pemenuhan terhadap hak-hak pekerja akibat terkena PHK terdapat dalam Pasal 1 Keputusan Menteri Tenaga Kerja Nomor Kep-150/Men/200 yaitu berupa:

1) Dana Pesangon

Dana pesangon ini dapat diuraikan sebagai ganti kerugian yang harus dipenuhi oleh pemilik usaha untuk pegawainya sebagai hasil dari perbuatannya yaitu mem-PHK pegawainya sendiri.

2) Dana Penghargaan Masa Kerja

Dana penghargaan masa kerja ini adalah sebuah ganti kerugian yang wajib diberikan pemilik usaha pada pekerjanya sebagai tanda atau penghargaan dalam lamanya kurun waktu pekerja tersebut bekerja.

3) Ganti Kerugian

Uang ganti kerugian ini merupakan upah yang diberikan oleh pemilik usaha kepada pekerja sebagai ganti kerugian yang dialami oleh pekerja/buruh yang bersangkutan akibat dampak dari PHK tersebut.

Namun, saat terjadinya Pemutusan Hubungan Kerja yang dikerjakan oleh pemilik sebuah tempat usaha toko modern yang berlokasi di Kota Denpasar, para pekerja di-PHK hanya mendapatkan 
uang pesangon berupa upah terakhir yang mereka terima di bulan terakhir bekerja. Peneliti mewawancarai salah satu pegawai toko modern yang berada di wilayah Denpasar yang mengatakan bahwa saat terjadinya PHK akibat Wabah Covid-19 ini, hak yang diberikan biasanya hanya berupa upah/gaji pada bulan terakhir pegawai bekerja karena memang pendapatan toko cenderung menurun sejak adanya Pandemi Covid-19 ini. (Wawancara dilakukan kepada Ibu Komang Ami salah satu pegawai Toko Modern AR Mart yang beralamat di Jalan Sedap Malam No. 68 pada tanggal 10 Oktober 2020).

Hal ini jelas bertentangan dengan peraturan perundang-undangan dimana jika dalam hal pemutusan hubungan kerja (PHK) terjadi atau dilakukan, para pengusaha harus memenuhi hak-hak pekerja dengan memberikan uang pesangon, uang penghargaan masa kerja, dan juga ganti kerugian. Hak-hak pekerja/buruh toko modern ini susah untuk dipenuhi karena memang keterbatasan saat membuat sebuah perjanjian kerja, karena toko modern di Denpasar yang tidak berjejaring cenderung hanya menggunakan perjanjian kerja secara lisan yang hanya mengandalkan unsur kesepakatan dalam hubungan kerjanya. Perjanjian kerja secara lisan inilah yang disebut juga dengan Perjanjian Kerja Waktu Tidak Tertentu (PKWTT).

\section{Perlindungan Hukum Bagi Pekerja Toko Modern Saat Di-PHK Akibat Dampak Pandemi Covid-19 di Kota Denpasar}

Menurut data yang diperoleh dari Dinas Perijinan Kota Denpasar dan Pusat Data Kota Denpasar bahwa keberadaan Toko Modern di Kota Denpasar tiap tahunnya semakin bertambah. Dari tahun 2014 hingga tahun 2018 terjadi kenaikan yang cukup signifikan. Peneliti sempat melakukan wawancara dengan Ibu I Ketut Anggreni yang menjabat sebagai Seksi Pengolahan Data dan Sistem Informasi Perencanaan Modal di Dinas Perijinan. "Memang setiap tahunnya perkembangan UMKM dan Toko Modern terus bertambah diikuti dengan pola masyarakat yang memang cenderung konsumtif setiap tahunnya. Terlebih memang kota Denpasar sendiri memiliki banyak penduduk pendatang dari berbagai daerah tidak hanya di Bali tetapi dari luar pulau Bali juga ada" (Wawancara dilakukan kepada Pegawai Dinas Perijinan Kota Denpasar yang bernama I Ketut Anggreni pada tanggal 21 Oktober 2020).

Tetapi sejak adanya Pandemi Covid-19 yang menyerang seluruh wilayah Indonesia tak terkecuali juga kota Denpasar sejak Maret 2020, mengakibatkan adanya penurunan penjualan di hampir seluruh toko modern yang ada di Kota Denpasar. Selain itu Pemerintah Kota Denpasar juga menetapkan peraturan dengan menerbitkan Peraturan Walikota Denpasar Nomor 32 Tahun 2020 tentang Pembatasan Kegiatan Masyarakat Di Desa, Kelurahan dan Desa Adat Dalam Percepatan Penanganan Coronavirus Disease 2019 (Covid-19) dimana dengan dibuat peraturan ini, masyarakat dihimbau untuk melakukan pembatasan sosial dalam masyarakat. Pembatasan sosial inilah yang mengakibatkan daya beli masyarakat yang biasanya cenderung konsumtif menurun terlebih terdapat pembatasan jam operasional yang diterapkan di kota Denpasar.

Melihat adanya aturan yang dibuat oleh Pemerintah saat pandemi ini berlangsung di Kota Denpasar. Hal ini sangat berimbas kepada penjualan toko modern yang ada di Denpasar. Para pemilik usaha Toko Modern yang sebelumnya mengoperasikan tokonya selama 24 jam kini harus menyiasati hal tersebut dengan mau tidak mau harus mengurangi jumlah pekerja/buruh pada toko mereka. Hal ini untuk menjaga eksistensi agar pengeluaran dengan pemasukan toko dapat tetap stabil. Pada hasil wawancara yang peneliti lakukan kepada beberapa pemilik usaha toko modern di daerah Kota Denpasar. didapatkan bahwa dari 10 toko yang ditemui, terdapat 3 toko yang sudah melakukan PHK karena efek dari wabah yang sedang berlangsung ini yaitu Toko Modern ZenMart, Toko Modern Puncak Karang dan Toko Modern AR Mart. Salah satu pegawai Toko Modern Puncak Karang bernama Ni Putu Dewi mengatakan bahwa memang benar pemutusan hubungan kerja di toko tersebut dilakukan secara akibat karena dampak dari pandemi Covid-19 sendiri. Penurunan penjualan mencapai hampir 30\% dan terpaksa mengurangi jumlah pekerja/buruh untuk pengelolaan toko juga berjalan dengan baik (Wawancara dilakukan kepada pekerja Toko Modern Puncak Karang yang bernama Ni Putu Dewi pada tanggal 10 Oktober 2020).

Dampak dari hal ini itu bisa membuat keretakan antara masyarakat itu sendiri karena biasanya PHK yang dilakukan bisa membuat suatu perselisihan kerja. Padahal sebenarnya suatu ikatan kerja antara kedua belah pihak isinya tidak boleh bertentangan dengan peraturan atau perjanjian yang mereka buat bersama maupun aturan undang-undang yang ada (Budiartha, 2016). Pekerja toko 
modern yang sebagian besar merupakan masyarakat yang status sosialnya menengah ke bawah hanya bisa pasrah ketika mereka di-PHK secara sepihak tanpa memahami perlindungan hukum apa yang seharusnya mereka dapatkan. Untuk perlindungan hukum itu sendiri dibagi menjadi perlindungan hukum preventif (perlindungan waktu kerja; perlindungan pengupahan dan kesejahteraan; perlindungan keselamatan dan kesehatan kerja) dan perlindungan hukum secara represif (perlindungan perselisihan hubungan industrial; perlindungan dalam pemutusan hubungan kerja). Biasanya upaya penanganan atau lebih dikenal dengan penyelesaian perselisihan suatu hubungan kerja itu sendiri dibagi menjadi 2 (dua) cara yaitu melalui sistem pengadilan dan sistem di luar pengadilan (Penggabean, 2007).

Untuk perselisihan antara pemilik usaha yang mempunyai Toko Modern yang ada di sekitaran Kota Denpasar dengan pekerja/buruh biasanya dilakukan penyelesaian perselisihan melalui bipartite atau perdamaian saja. Ini dikarenakan perjanjian yang dibuat antara pihak satu dengan pihak yang lainnya merupakan hanya berupa perjanjian secara lisan dimana mengandalkan kesepakatan dan juga asas kepercayaan dalam hubungan kerjanya sehingga jika para pihak berselisih dan ingin menyelesaikan dalam jalur litigasi akan sangat sulit karena bukti secara tertulis bahwa terdapat hubungan kerja antar para pihak sangatlah minim.

Untuk perlindungan hukum yang bersifat represif seperti perlindungan hukum pada saat terjadi pemutusan hubungan kerja, para pekerja tidak mendapatkan perlindungan sesuai pada aturan hukum yang berlaku atau Undang- Undang. Hal ini dikarena ketidakmampuan pemilik usaha toko modern untuk memenuhi hal tersebut. Wawancara dilakukan kepada Pemilik Toko Modern ZenMart yang mengatakan bahwa karena Covid-19 ia terpaksa mem-PHK pekerja/buruhnya tersebut dengan memberikan upah berupa uang di bulan terakhir buruh tersebut bekerja. Ini juga sudah dilakukan sesuai kesepakatan antara para pihak yang bersangkutan. Melalui wawancara yang dilakukan kepada Pemilik usaha toko modern ZenMart pada tanggal 10 Oktober 2020 dengan Bapak I Nyoman Widnya, ia mengatakan mereka terpaksa merumahkan pegawai, dan syukurnya sampai sekarang tidak pernah ada yang melakukan protes atau tidak menerima hal tersebut karena pegawai kami memahami situasi dan kondisi toko sejak memang adanya pembatasan jam operasional yang diberlakukan di Denpasar akibat adanya Covid-19 ini dan memang kami terpaksa melakukan ini karena untuk mengefisiensikan kinerja pegawai di toko ini. Mengingat hal tersebut, pekerja/buruh yang terkena PHK khususnya pekerja/buruh pada toko modern di Kota Denpasar harus mendapatkan perlindungan hukum sebagaimana yang telah diatur dalam Pasal 166 sampai Pasal 172 UU No. 13 Tahun 2003 yang pada dasarnya pekerja berhak mendapatkan uang pesangon, uang penghargaan masa kerja, uang penggantian hak sesuai dengan masa kerja dan jenis PHK yang diberikan sesuai kesepakatan kerja yang dilakukan antar pihak, dan juga harus sesuai dengan aturan yang berlaku baik sekarang maupun yang akan datang nantinya.

\section{SIMPULAN DAN SARAN}

\section{Simpulan}

Berdasarkan hasil dan pembahasan di atas, simpulan yang dapat ditarik adalah: dalam upaya melakukan perlindungan hukum terhadap para pekerja toko modern yang terkena PHK secara sepihak, pemerintah telah mengeluarkan beberapa peraturan terkait permasalahan pengakhiran ikatan kerja yang dilaksanakan pemilik usaha. Selain itu, hak-hak para pekerja yang terkena PHK harus diperhatikan seperti pemberian uang pesangon dan ganti kerugian serta menjamin perlindungan hukumnya dengan memberikan perlindungan hukum secara preventif dan represif agar para pemilik usaha tidak sewenang-wenang melakukan PHK.

\section{Saran}

Ada juga beberapa saran yang perlu disampaikan berdasarkan hasil penelitian ini, yaitu: pemerintah perlu melakukan peningkatan dan pengkajian lebih dalam terhadap beberapa aturan hukum yang sudah diterapkan di masyarakat. Utamanya hal ini diharapkan perhatian dari segala aspek tidak hanya pemerintah atau petinggi negara saja bahwa pekerja/buruh khususnya yang masih menggunakan perjanjian lisan dalam hubungan kerjanya untuk dibuat pengaturan perlindungan hukum yang lebih baik lagi. 


\section{DAFTAR PUSTAKA}

Budiartha, I. N. P. (2016). Hukum Outsourcing Konsep Alih Daya Bentuk perlindungan dan Kepastian Hukum. Malang: Setara Press.

Hakim, D. A., \& Ispriyarso, B. (2016). Pemenuhan Hak-Hak Tenaga Kerja melalui Penerapan Corporate Social Responsibility pada suatu Perusahaan (Studi Penerapan CSR Di PT. Great Giant Pineapple, Provinsi Lampung). Jurnal Law Reform, 12(2), 197-208.

Muhyiddin. (2020). Covid-19, New Normal dan Perencanaan Pembangunan di Indonesia. The Indonesian Journal of Development Planning, 4(2), 240-252.

Penggabean, H. . (2007). Hukum Acara Penyelesaian Perselisihan Hubungan Industrial. Jakarta: Jala Permata.

Setiawan, I. K. O. (2018). Hukum Perikatan. Jakarta: Sinar Grafika.

Sholeh, M. (2007). Permintaan dan Penawaran Tenaga Kerja serta Upah: Teori serta beberaoa Potretnya di Indonesia. Jurnal Ekonomi \& Pendidikan, 4(1), 62-75.

Suratman. (2019). Pengantar Hukum Ketenagakerjaan Indonesia. Depok: PT Raja Grafindo Persada.

W, Y. Y., Sulastri, \& R, D. A. (2018). Implementasi Undang-Undang Ketenagakerjaan dalam Perjanjian Kerjaan antara Perusahaan dan Tenaga Kerja di Perseroan Terbatas (PT). Jurnal Yuridis, 5(2), 186-209.

Wijayanti, A. (2010). Hukum Ketenagakerjaan Pasca Reformasi (2nd ed.). Jakarta: Sinar Grafika. 